\title{
Neural correlates of a search strategy
}

Dominique Martinez

From 1st International Workshop on Odor Spaces

Hannover, Germany. 4-7 September 2013

Abstract available at http://www.plosone.org/article/info \%3Adoi\%2F10.1371\%2Fjournal.pone.0061220 [1].

Published: 16 April 2014

\section{Reference}

1. Martinez D, Chaffiol A, Voges N, Gu Y, Anton S, Rospars J-P, Lucas P:

Multiphasic on/off pheromone signalling in moths as neural correlates of a search strategy. PLoS One 2013, 8:e61220.

doi:10.1186/2044-7248-3-S1-O26

Cite this article as: Martinez: Neural correlates of a search strategy. Flavour 2014 3(Suppl 1):026.

Submit your next manuscript to BioMed Central and take full advantage of:

- Convenient online submission

- Thorough peer review

- No space constraints or color figure charges

- Immediate publication on acceptance

- Inclusion in PubMed, CAS, Scopus and Google Scholar

- Research which is freely available for redistribution

Submit your manuscript at www.biomedcentral.com/submit

\section{Ciomed Central}

